\title{
Acquisition of Environmental Awareness: The Interplay with Institutional Development
}

\author{
Janna Smirnova ${ }^{1}$ \\ ${ }^{1}$ Department of Economics, Statistics and Finance, University of Calabria, Cosenza, Italy \\ Correspondence: Janna Smirnova, Department of Economics, Statistics and Finance, University of Calabria, \\ Arcavacata di Rende, Cosenza, 87036, Italy. Tel: 39-098-449-2444. E-mail: janna.smirnova@unical.it
}

Received: January 15, 2018

Accepted: February 10, $2018 \quad$ Online Published: February 20, 2018

doi:10.5539/ijef.v10n3p168

URL: https://doi.org/10.5539/ijef.v10n3p168

\begin{abstract}
Acquisition of environmental awareness is undoubtedly a necessary step towards environmental progress. However, due to the complex and interdisciplinary character of the argument, only a little literature has emerged regarding this issue. The paper contributes to fill in this lacuna and investigates the main factors responsible for the acquisition of environmental awareness from the institutional perspective. The acquisition of environmental awareness is seen as an interactive process involving institutional transformation and cognitive responses. The analysis shows that enforcement of formal rules and purposeful construction of informal rules contribute to create a favourable framework for such an acquisition. In enhancing environmental concern, a policy maker should allocate additional resources to formal rules enforcement, while informal rules should be accounted for by considering cultural backgrounds and human capital. Formation of environmental awareness through the spread of environmental education is argued to be a functional tool. The analysis leaves much space for further multidisciplinary research on environmental awareness and could serve as a starting point for the development of an empirical analysis of its determinants.
\end{abstract}

Keywords: economic development, environment and growth, environmental economics, human development, institutions and growth

\section{Introduction}

Increasing concern about environmental degradation urges us to search for prompt solutions at a global level. This task is very ambitious given the high heterogeneity of countries from an environmental perspective. Numerous factors are in play at an international level: pollution export, production delocalisation as well as intensive consumption of resources can be noted for developed countries, while high pollution levels, resource curse and depletion can be highlighted for developing and lagging behind economies. Environmental regulations that are stringent in the former and merely existing in the latter have not yet produced sufficient global results and the goal of environmental improvement is still far from being achieved. Clearly, for environmental issues, an international framework is of major importance.

Despite the heterogeneity, environmental policies have been demonstrated to be a functioning tool for improving environmental quality. The empirical evidence on the inverted $\mathrm{u}$-shape relationship between economic growth and pollution, known as the Environmental Kuznets Curve confirms the importance of policies put in act to achieve the turning point (for an overview see Dasgupta, Mody, Roy, \& Wheeler, 2001; Dinda, 2004; Gassebner, Lamlay, \& Sturmz, 2011), after which, environmental quality improves with increasing welfare. In fact, environmental improvements are hardly possible without the intervention of a regulator. The evidence of the EKC found for different polluters demonstrates most developing countries have not yet connected economic growth and environmental progress (Castiglione, Infante, \& Smirnova, 2014). While it is not surprising that the stage of economic development is important when considering environmental policies, what are less obvious are the decisive factors that prompt a society to initiate environmental progress.

The question we try to answer in this paper is what pushes a society to become environmentally aware? First of all, it is clear that there can be some extreme external and internal constrictions. These could be, for example, desperate environmental conditions, the forced entering into international unions or organisations, or other factors. At the same time, the appearance of environmental awareness can also be due to a conscious choice of an environmental friendly way of development. What then are the factors that call for environmental awareness? 
What is the trajectory that leads a society to become aware?

There is a striking lack of evidence on the determinants of environmental awareness in the literature. The answer to this question probably lies in the intersection of various disciplines, such as sociology, law, economics, education and others. In this work we try to delineate the main features on which environmental awareness could be based, emphasising that an institutional framework could be a good starting point for the development of a multidisciplinary perspective and further empirical analysis.

We start from the existing literature related to this argument so as to underline the novelty of this study which consists in adopting an institutional analysis approach that highlights the role of formal and informal rules in the acquisition of environmental awareness. Firstly, the role of institutions and their development for environmental progress is discussed. Then, possible sources for the acquisition of environmental concern are analysed. Attention is concentrated on the role of formal rules for appearance, divulgation and development of environmental awareness. The emphasis is then put on the composition and the impact of the factors that constitute informal rules. Finally, we provide a general scheme that highlights the mechanism of the interrelationship of institutional transformation and acquisition of environmental awareness where, as we argue, both phenomena may reinforce each other.

\section{State of Art}

The factors responsible for acquiring environmental awareness have been rarely studied to date. So far, the argument has been analysed from the following multidisciplinary perspectives. The first strand of literature analyses the appearance of environmental awareness at the micro level, such as at that of firms, involved in production and in services (Perron, Co`te, \& Duffy, 2006; Min, 2011; Yakita \& Yamauchi, 2011; Yu, 2012; Chan, Hon, Chan, \& Okumus, 2014). This qualitative and quantitative evidence discusses the reasons and the means of introduction of green practices and their consequences in terms of a firm's performance. The studies are normally based on applying managerial and business approaches. There has also been some analysis of this field based on economic modelling (Yakita \& Yamauchi, 2011; Yu, 2012).

Another strand of literature concentrates attention on the ways of acquiring environmental awareness through the education system at different levels of schooling and universities (Tranter, 1997; Selby, Jones, \& Kagawa, 2009; Stafford, 2011; Hassan, Noordin, \& Sulaiman, 2010; Viorica-Torii, 2013). This research is mostly based on social and behavioural approaches. The evidence of qualitative research emphasises the importance of educational methods, training in green practices and promotion of a sustainable way of living. Yet, the factors and conditions responsible for the adoption of environmental practices in educational institutions have been also identified by some empirical studies (Stafford, 2011). Finally, Hassan et al. (2010) and Yan, Kang, Wang, Lin, $\mathrm{Zhu}$, Liu, Sun, Li, and Jin (2011) provide interesting results regarding the determinants of environmental awareness at a local level, stating that the public participation in environmental programmes encourages environmental awareness. Yan et al. (2011) also confirm that for environmental awareness education has a significant importance. The absence of any empirical analysis of environmental awareness at a more global perspective can be noted.

This work, instead, is mostly related to the strand of literature that concentrates on the links between environmental awareness and institutions. Regarding this relationship a small amount of literature has emerged with very scarce empirical evidence. A few studies put in evidence the role of some particular types of institutions in relation to environmental concern. Weisbuch (2000) concentrates attention on the emergence of informal institutions, while Innes (2013) and Ebnesson (2010) put emphases on formal rules, expressed through legitimacy and liability. Scarce empirical evidence is provided for the definition of the determinants of environmental awareness, and this mostly at a local level (Yan et al., 2011).

Our analysis relies upon the aforementioned studies in several respects. First of all, the attempt is to unify the results provided by previous research so as to shift the vision of the problem to a more general level. Such an approach has the aim of defining crucial elements necessary for the acquisition of environmental awareness at a society level, which is useful, first of all, for environmental policy recommendations. Secondly, a key difference of our work is the focusing of attention on the importance of the role of the institutional context. This approach seems to have a general character since it permits us to analyse a wide range of aspects, based on formal and informal rules, responsible for the acquisition of environmental awareness and consider their interactions. Analysing the problem from the institutional perspective could give useful insights for further multidisciplinary analysis and for providing empirical evidence. 


\section{The Links between Environment, Institutions and Economic Development}

The definition of environmental awareness can be drawn from a milestone of environmental education such as the Tbilisi Declaration, released as a result of an intergovernmental conference organised by UNESCO and UNEP. The conference was held in Tbilisi in 1977, with the participation of 66 member-states and a large number of international nongovernmental organisations and observers. The Declaration signed at this meeting delineates environmental awareness as the acquisition of a basic understanding of the environment and its allied problems, development of a sensibility to the environment and the acquisition of a set of values to participate in environmental improvement and protection (Tbilisi Declaration, 1977). The document emphasises the necessity to develop environmental knowledge through the links with legislation, policies, measures of control, and regulator decision-making, recalling the importance of the ethical, social, cultural and economic dimensions. This vision of environmental awareness underlines the essential role of institutions.

In order to analyse the interrelationship between environmental awareness and the institutional context, we have firstly to recall the most important features of institutions. We will refer here to institutions as in the definition provided by the founder of institutional economics, Douglass North $(1989$, p. 1321): "Institutions are rules, enforcement characteristics of rules, and norms of behaviour that structure repeated human interaction". Relying on this definition, it is clear that institutions represent a pillar for the environmental awareness of the society given that environmental concern is undoubtedly based on formal and informal rules that constitute the institutional context itself.

Promoting the institutional context could be an essential component of a common endeavour to build a more environmentally aware world. However, the mechanisms of institutional enforcement are still an open question. It is well known that assistance in the development of institutions has become an increasingly central component in our society, and huge resources have been channelled toward strengthening institutions in lagging behind economies; however, with still little success. In fact, as Haggard, MacIntyre, and Tiede (2008) argue, the instalment of a new institutional framework is a long process and it is misleading to think that institutions can be readily transferred elsewhere. A classic example of a hazardous transfer of institutions is the switch of former communist countries toward the market. The institutional vacuum created after the demolition of planned economy institutions has not yet been substituted with market economy institutions in many former communist economies. Whether their institutional context is comparable to those in Western Europe is still an open question.

A wide range of empirical literature provides the evidence of the links between environmental quality, economic development and the enforcement of institutions. It is argued that societies characterised by protection of property rights, democratisation, control of bureaucracy and a stable legal system are those that not only obtain higher standards of living, but also greater environmental progress (Bhattarai \& Hammig, 2004; Baek, Cho, \& Koo, 2009; Leitão, 2010; Iyoboyi \& Na-Allah, 2015). This result could be a good starting point for the analysis of environmental awareness. Would enforced institutions create a necessary basis also for its acquisition?

In answering this question, we have to keep in mind the following empirical puzzle. Although the positive effect of a strong institutional context on economic development and growth has achieved the status of received wisdom, many emerging countries, such as Eastern Asian countries, with still excessive lacunae in their institutional enforcement, obtain extremely high growth rates. At the same time, these countries, being producers of a large part of goods consumed in the world, are also characterised by rapidly deteriorating environmental conditions. On the other hand, there are economic leaders, for example the United States, that despite their strong institutional context and high living standards, are not always prompt to adhere to international environmental protocols. This evidence confirms the complexity of the links between economic development, institutional enforcement and environment, which are still far from being clearly understood.

Analysing the data of World Values Survey (2017), it is possible to illustrate a general picture of environmental awareness in the world. The World Values Survey provides a series of surveys that covers a wide range of topics concerning human values. Environmental issues are also considered. In particular, it contains the question of whether protecting the environment should be given a priority in respect to favouring economic growth. The number of positive replies to this question, expressed as a percentage of total answers, could be used as a proxy to measure the environmental awareness of countries, as represented in Figure 1. 


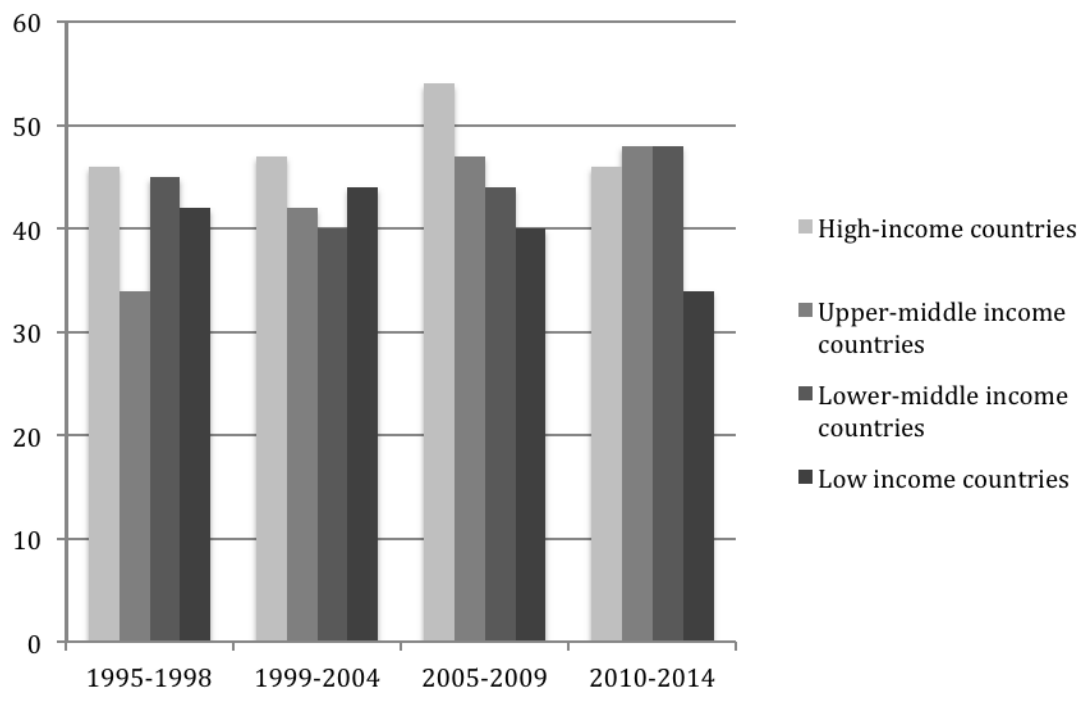

Figure 1. Environmental awareness in the world

From Figure 1, the general increasing trend of environmental awareness in the world from 1995 till 2014 can be noted. High-income and upper-middle income countries demonstrate a high percentage of interviewed population that opt for environmental progress. The trend however is changing in high-income countries and is slowing down in upper-middle income countries in the last period, which covers the world economic crisis. Lower-middle income countries demonstrate that a relatively high percentage of the population is opting for environmental progress. It is interesting to note that environmental awareness in upper-middle and lower-middle income countries has converged and become higher over the period. In turn, low-income countries, in recent years, have a somewhat lower percentage of the population environmentally aware and their trend is negative. This illustration of the dynamics of environmental awareness in the world in the last two decades probably indicates the relationship existing between environmental awareness and the degree of development of societies.

\section{Acquisition of Environmental Concern}

In order to understand factors which are crucial for environmental awareness, we first make an attempt to delineate the mechanisms of acquiring environmental concern. The mechanism with the most immediate effect is that due to serious environmental damage. A drastic deterioration of environmental conditions that has destructive effects on the people's way of living and health forces people to realise the importance of the immediate introduction of the measures of environmental control. For example, Yan et al. (2011) observe a significant increase of environmental concern in Shanghai between 2007 and 2011. The most important causes are given as the drastic deterioration of environmental conditions, such as temperature increase and worsening of air quality. In fact, the images of people wearing protection masks in metropolises of China are well-known.

Another channel through which environmental awareness surges is through exogenous constrictions. For many transition and emerging economies, becoming part of international organisations, unions of countries or gaining access to foreign investments can be conditioned by the introduction of severe environmental standards imposed by "stronger" economies. The effects of these practices depend on the effective willingness of the state to take care of the environment. Not environmental, but still a striking example of institutional transfer is provided by Carter (2007) who refers to an interview released by Loskutovs, a chief of the anti-corruption bureau in Latvia. "Latvia's goal is to not fight corruption - it was to get into the EU and NATO. Creating an anti-corruption authority, he added, was a part of the checklist". This scenario could be easily projected in the prospective of environmental protection. Fortunately, most former transition European economies, for example, have introduced and maintained structures responsible for environmental control required by the European Union. With time the imposed restrictions have been absorbed, modifying citizens' norms and behaviour so that environmental concern has become deeply rooted. It should be noted, however, that undertaking environmental restrictions is not necessarily a duty, but very often a consequence of the positive influence of neighbouring countries. In fact, it has been observed by Weisbuch (2000) that having an ecologically concerned neighbour has a positive effect on the environmental performance of countries.

Another possible channel through which environmental awareness can be achieved is noted by analysing the 
eco-leader countries such as Denmark, the Netherlands, Norway, Sweden and the United Kingdom. These countries, positioned on the frontier of environmental progress, have experienced neither severe environmental degradation nor constriction to adhere to environmental practices. No doubt, some mechanisms have worked to make society understand the gravity of the status quo so prevention mechanisms are being launched. Clearly, this channel is the most desired scenario given that it activates an ex-ante mechanism of environmental protection and assures the timelines of intervention. The question is then what is in the black box: what are the forces that wake-up environmental awareness in a society?

We should bear in mind another possible channel for the appearance of environmental awareness, that of innate awareness. Among lagging behind countries, where the way of living is directly related to nature, environmental awareness normally has deep roots. Severe climatic conditions and the lack of water limit possibilities for agriculture or stock raising, for example in African countries, and have produced a culture of deep respect for the environment and for a harmonised relationship between people and nature. However, it should be noted that very often the tradition of the respect for nature in lagging behind economies is contrasted by the search for rent. Many African countries are the destination for the disposal of waste which is produced by the developed world. One of the most recent examples is the accumulation of electric and electronic waste, which is the fastest growing waste stream of the planet (OECD, 2008). Exhausted by desperate living conditions, the local population earns by decomposing electrical and electronic waste in search of chemical components, that are sold in change for little money (Castiglione, Infante, \& Smirnova, 2018). This mechanism works despite traditional respect for nature, whcih highlights the indisputable importance of economic welfare for environmental progress, inseparable from the enforcement of institutions.

\section{Formal Rules}

\subsection{The Role of Legal Context}

Considering environmental awareness from an institutional perspective, we start by discussing the role of formal rules. Formal rules are those that create a terrain for environmental awareness given that they provide a predictable and stable world without which any cognitive development would be difficult to achieve (Rindermann, 2008). Stability and predictability are two important aspects of formal rules that can be discussed by referring to the rule of law. This institution, as argued (Castiglione, Infante, \& Smirnova, 2014), represents a valid proxy of formal rules. Numerous definitions of the rule of law describe it as a principle of governance that ensures adherence to the principles of supremacy of law, equality before the law, accountability of the law, fairness in the application of the law, separation of power, legal certainty, avoidance of arbitrariness and procedural transparency (summarised by Portela, 2012, on the basis of OECD definition). From this dimension of the rule of law, it is easy to deduce that a society with strong formal rules obtains a predictable world in which problems can be solved and aims be reached by effort, by the use of intelligence, rather than by coercion, personal connections and bribery (Rindermann, 2008).

In the empirical literature, rule of law is accounted for in different ways (for a discussion thereof see Haggard and Tiede, 2011), such as through mitigation of violence, protection of property rights, legal origins, control over government and corruption control (Donnelly, 2006; Gradstein, 2004; Grossman, 2001; Beck, Demirguc-Kunt, \& Levine, 2003; Acemoglu, Johnson, \& Robinson, 2001).

As recent research demonstrates, the rule of law has an important influence on the environment, given that it is crucial for the introduction, functioning and enforcement of environmental policies (Castiglione, Infante, \& Smirnova, 2014). From the environmental perspective, formal rules matter because they not only mark out rights, obligations and responsibilities, but also define what is permitted, who has the power to do what, and the consequence of different acts (Ebbesson, 2010). Moreover, given that environmental improvements rarely occur without regulator intervention, formal rules and, particularly rule of law, play a central role since, as stated by Ebbesson (2010), regulator power also becomes subject to legal constraints, requirements and sanctions, and providing trust in government. In fact, models that give importance to the rule of law for environmental issues, often implicitly or explicitly, identify government predation as a constraint. In this context, rule of law enforcement is a cornerstone for socio-ecological systems, where the quality of institutions is fundamental for policy applications.

The establishment and maintaining of a strong rule of law is a long and complex process, that depends on deeply rooted and accepted ideologies. Dawson (2013) describes two countries with similar historical, social, cultural, economic, and political realities, such as Jamaica and Barbados, both former English colonies. The countries have strongly different rule of law levels, with Barbados's state promoting rule of law, while Jamaica's is deteriorating. The roots of these differences, according to the authors, are based on class formation, religion and 
cultural development. It is not always sufficient to maintain legal institutions to obtain stronger rule of law since it also depends on the characteristics of society, its historical context and politics.

In considering, for example, Western European countries, it can be supposed that these economies can cope more successfully with environmental problems compared to Central or Eastern European countries because their legal systems are more functional. We can make an attempt to analyse the relationship between rule of law enforcement and environmental performance. Table 1 provides information of the rule of law index for four groups of countries for the period 1996-2016. The data on the rule of law is provided by World Governance Indicators (World Bank, 2017); the rule of law is a composite index that ranges from -2.5, that corresponds to the lowest rule of law level, to +2.5 , that corresponds to the highest rule of law level.

The positive trends of the rule of law enforcement for some well-performing Western European eco-leaders are shown in the first group of countries. As can be seen, rule of law, which was already at very high levels, decisively increased during the period of observation.

Table 1. Rule of law change in developed and emerging countries

\begin{tabular}{lccclccc}
\hline & $\begin{array}{c}\text { Rule of } \\
\text { law 1996 }\end{array}$ & $\begin{array}{c}\text { Rule of } \\
\text { law 2016 }\end{array}$ & $\begin{array}{c}\text { Index } \\
\text { change\% }\end{array}$ & Rule of law & Rule of law & Index \\
change $\%$
\end{tabular}

Note. Elaborations based on World Governance Indicators (2017).

The second group includes some Central European countries. Despite their attempts to import Western European institutions, these countries have had a tortuous switch versus a market economy and are still characterised by a weaker rule of law. However, as Table 1 illustrates, their lower levels of the rule of law, compared to the previous group of countries, demonstrate a significant increasing trend in the last two decades.

Western European countries, however, can also have unpleasant institutional dynamics. These countries are those that are experiencing hard times in terms of financial, social, and political aspects: Portugal, Italy, Greece and Spain are included in this third group. As can be seen from Table 1, their rule of law index is not only decisively lower than that of other Western European countries, but are also drastically decreasing, with the exception of Spain that demonstrates a positive performance. For the sake of comparison, Table 1 also represents emerging countries such as BRICS, in the fourth group. These economies are characterised by extremely low and almost all negative rule of law values. However, except for India, a slow improvement of the legal rules can be noted.

What conclusion can be drawn from Table 1 from the point of view of the environment? Empirical evidence clearly has shown the important positive impact of rule of law enforcement for environmental quality, for application of environmental policies and for environmental progress. Therefore, the institutional paths captured in the table can give some idea also about environmental performance. In fact, in the first group we find countries that, apart from the stringent rule of law, are also characterised by an excellent environmental protection experience, in fact, these countries are also known as eco-leaders (Ekins, Summerton, Thoung, \& Lee, 2011). In turn, the Central European countries of the second group, are those that have recently introduced environmental policies, enhanced by European Union requirements. The environmental performance of these countries is constantly improving. In turn, some countries of the third group, are well known for the sad experience of their illegal waste recycling management (Bonini, 2008) and scarce regulator capacity in monitoring environmental policies application (Infante \& Smirnova, 2016). Although among the BRICS group 
countries we find major world polluters such as China and India, these emerging countries are also those that recently have invested to improve their environmental performance (Song, Zhang, Liu, \& Fisher, 2013), which together with the improvement of institutional context could constitute a promising ecological scenario.

To support the hypothesis of the links between environmental concern and institutional strength, interesting information can be extracted from the last wave of World Values Surveys (2014) covering the period 2010-2014. As noted above, the Survey gives information that can be seen as a proxy of environmental awareness. Unfortunately, not all of the countries in the analysis are covered by the survey, so we take into consideration the average values of the groups of available countries. Ecological leaders have a very high percentage, of around $65 \%$, of the interviewed population that gives priority to environmental protection compared to economic growth. The BRICS group also demonstrates a significant part of the population that gives priority to the environment, of around $50 \%$. The percentage, however, differs for former transition countries that are still reluctant to face environmental problems and is around 44\%. The countries that would dedicate fewer resources to the environment are, unsurprisingly, European countries of the third group; these countries have an unstable economic, social and political framework. In this group, on average, only $37 \%$ of the interviewed population can be considered sensitive to the environment.

As our investigation demonstrates, the enforcement of legal rules and, particularly, of the rule of law, is strictly related to the degree of environmental concern present in society. For this reason, the enforcement of rule of law should be considered by a policy-maker as a valid tool for the achievement of an environmentally aware society.

\subsection{Resilience of Formal Rules}

The introduction and development of new institutions is a long process that depends on the continuous support and endorsement of people. Deeply rooted and accepted ideologies are able to create obstacles to institutional development, which calls for the inseparability of the formal and informal rules forming the institutional context. As we have seen, rule of law, particularly, has multiple dimensions, so there are some complementarities that can be expected to promote or retard economic growth, as well as environmental quality.

In the literature, there are well-defined reasons for why formal rules may not always be efficient. An important characteristic of formal rules is their resilience. The lack of resilience can be the reason for the difficulties in importing or transferring the formal rules between societies while adopting a certain institutional context. Despite the static and fixed nature of the law, as argued by Ebbesson (2010), in some situations other values and ethical concerns may override the value of legal rules, since legal certainty may sometimes simply be unfair or discriminatory. For example, Liang and $\mathrm{Wu}$ (2013) demonstrate that in countries where the population is aging the introduction of higher social security benefits may lead to a lower environmental quality.

In the environmental perspective where uncertainty is high due to the intensive technical processes, resilience of formal rules is an important factor. Folke (2006) and Ebbesson (2010) argue that resilience permits a convergence of social and ecological systems, placing legal considerations in the centre. In fact, in the absence of resilience, rigid legal regulations may fail to promote adequate environmental awareness. This happens since environmental issues presume the presence of decision-making processes (Weisbuch, 2000), where agent's actions impinge on the status of the world and the resulting changes of the environment modify agents' behaviour. If drastic environmental change happens, effective decision-making becomes crucial to mitigate environmental damage as well as to adapt to new circumstances. In this framework, agents' interactions may unfold and shape the formal rules.

However, resilience itself may depend on the rule of law. This is because in regulating environmental issues, rule of law not only defines rights and duties, but also takes on an instrumental character (Ebbesson, 2010), influencing social trust, the legal system and protection of rights, which calls for a certain degree of flexibility in the system. In this regard, Walker and Salt (2006) and Folke (2006) argue that society should be flexible enough to face the uncertainty rather than atttempt to control nature, and institutions must be open enough to promote the process of adaptability. Consequently, as again Ebbesson (2010) argues, the challenge remains of finding appropriate relations between legal rules and resilience. On the one hand, legal rules should acquire an open-textured character, permitting flexibility. On the other hand, legal rules should guarantee that the regulator acts within the limits of discretion imposed by laws.

\section{Informal Rules}

\subsection{Cognitive Abilities}

The interaction mechanism of formal rules and resilience calls for another important component for the acquisition of environmental awareness that, however, already resides within the mechanism itself. This 
component consists of the formation of informal rules that are a part of the institutional context. As noted above, informal rules, such as common beliefs, traditions, convictions, cultural backgrounds and others have a strong influence on both formal rules and resilience.

The formation of informal rules and their composition are decisive for acquiring environmental awareness. Viorica-Torii (2013) argues that in order to awaken sensibility, environmental ethics should be incorporated into society since they contribute to improving the building up and reassessment of human behaviour towards nature. Ethics, in turn, is the result of the development of moral values such as attitudes towards environmental protection, which is impossible if there is no understanding. Adoption of environmental practices implies that members of society are aware of the state of the nature as well as of the effects of the interaction with the surrounding environment. Environmental awareness comes only when understanding of environmental problems is embraced into society at an individual level.

For these reasons, among the multiplicity of informal rules that reinforce environmental awareness those that are linked to cognitive abilities are most relevant. Cognitive abilities, according to Bernstein, Penner, Clarke-Stewart, and Roy (2006) can be defined as the capacity to perform higher mental process of reasoning, remembering, understanding, problem solving and decision-making. Therefore, from an environmental perspective, cognitive abilities are fundamental since they establish the recognition and respect for the rights, definition of duties, reciprocity, understanding the interests of others, and defining of social interactions. These social interactions are essential also for the building up of strong institutions. In fact, cognitive abilities measured through intelligence and knowledge are demonstrated by empirical literature (Rindermann, 2008) to contribute positively to institutional enforcement.

We can again think of the argument by inverting causality relationships. Societies characterised by a strong institutional context are proved to have also informed, intelligent and rational citizens. As discussed by Kaufman (2009), intelligence is required at macro and at micro-social levels, given that it influences any decision-making process and defines the quality of administration, legal system and governance. Since rule of law promotes intelligence and knowledge, in societies characterised by a strong rule of law, the development of cognitive abilities is enhanced and environmental awareness can be easily acquired.

Cognitive abilities are also closely linked to the economic wealth of society (Weede, 2006), given that they stimulate economic development and are also supported by it. This is another reason why the environmental awareness of a society is necessarily linked to the degree of development. Civil societies that promote strong institutions, education and intelligence create the necessary framework for the diffusion of environmental awareness. Instead, for countries where a regime of instability rules, the environmental concern is clearly obstructed. For example, an unstable institutional framework created as a result of a drastic institutional change, as had happened in Central and Eastern European countries, led to fragility and uncertainty of the system. As a consequence, negative trends in social interrelations contributed to the appearance of separative factors in the maintenance of common values (Bugaric, 2008). As is known, these countries are also characterised by weaker environmental performance in respect to their Western European counterparts. We can, therefore, conclude that economic wealth, political stability and institutional enforcement create a favourable framework for the acquisition of environmental awareness through enhancing the process of cognitive development.

\subsection{Education as a Tool of Acquisition}

The development of cognitive abilities that contribute to the creation of a favourable set of informal rules can be achieved through education (Barber, 2005). Better education makes people share the values constructed on strong institutions more easily and rational decisions taken in society are then greatly facilitated.

Education can be seen as a valid tool to diffuse environmental awareness. As Dee (2004) argues, educated people are better and more easily informed, have robust moral judgment and dynamic cultural enrichment. Education, therefore, may have a relevant effect on environmental awareness given its impact on rational choices, better information processing and ethical effect, which itself depends on cognitive ability, given that cognitive development is a prerequisite for moral development (Rindermann, 2008).

There are a lot of examples of the promulgation of education in an environmental perspective. Particular attention is given to the early education, such as in primary and secondary schools. In fact, formation of informal rules is easily enhanced in the early years. Many emerging economies, where environmental conditions represent threats, start introducing environmental programmes at schools. For example, in Malaysia, following UNESCO (1999) directives on environmental education, programmes related to environmental education include courses that aim to increase environmental concern, to give knowledge about laws and policies aimed at increasing environmental conservation and at enhancing noble values that increase the appreciation of the environment 
(Yan et al., 2011).

Environmental education programmes are, however, more diffused at university level, even though still at a pioneering stage (Selby et al., 2009). In this case these programmes not only aim to enhance environmental awareness, but also to improve the image of the university, and so attract students. Financial resources are fundamental for the decision to adhere to environmental practices. As Stafford (2011) notes, environmental support is still a luxury good for universities. This confirms the importance of a policy maker intervention to provide necessary resources designed appositely for the formation of environmental awareness through the spread of environmental education.

\section{Completing the Puzzle}

To sum up the process of the acquisition of environmental awareness, we can put the above consideration into a general scheme. Figure 2 represents the interaction between environmental awareness and institutional context. As noted above, institutional awareness, represented in the centre of Figure 2, can be acquired through different channels: innate acquisition, acquisition through knowledge and acquisition through constrictions that can be, in turn, due to social constrictions or due to drastic environmental degradation. Acquisition through knowledge and through exogenous social restrictions, in turn, implies the involvement of a cognitive process. This process can be based on the development of scientific knowledge founded on education or on the importation of environmental practices adopted by other societies. In turn, innate awareness goes through another route, given that it is not based on scientific knowledge but on traditions, norms of behaviour or convictions. This channel together with the two above channels has a strong influence on shaping institutional context.

The last channel, that of drastic environmental degradation, does not have a closed loop with institutions. This is because this type of awareness acquisition is not founded on institutional change but, however, it is also fated to change the institutional context, as other channels do. In fact, as represented in the upper part of Figure 2, once environmental awareness is acquired through the channels, it puts in action the mechanism of institutional transformation by influencing the formation of formal and informal rules.

We can detect another mechanism linking institutions and environmental awareness. This mechanism is linked to environmental predation, i.e. extracting rent from actions that simulate environmental concern. These types of rent-seeking contribute to the formation of distorted knowledge of the environment and, instead of contributing to the acquisition of environmental awareness, create distortions and provide rents for self-interested economic agents involved in the game. This process, without doubt, has a strong, but negative impact on institutions. One of the examples of this scenario is the mining project of Peru in the Cajamarca region (Leon \& Kraul, 2013). The lagoons located in this region are the source of water for the residents and for local agriculture. The largest mining investment in the history of the country is aimed at the extraction of gold situated in the lagoons. This creates a credible threat for the ecosystem. The promoters of this investment have tried to launch different companies to influence the opinion of the population concerning the neutrality of the environmental consequences of the mining. Political crisis and regional clashes were the consequences of this unresolved situation.

Finally, as shown in Figure 2, environmental awareness not only implies institutional change, but it is also influenced by the feedback of institutions. In fact, the interrelationship between environmental awareness and institutional context is presented as a closed loop. 


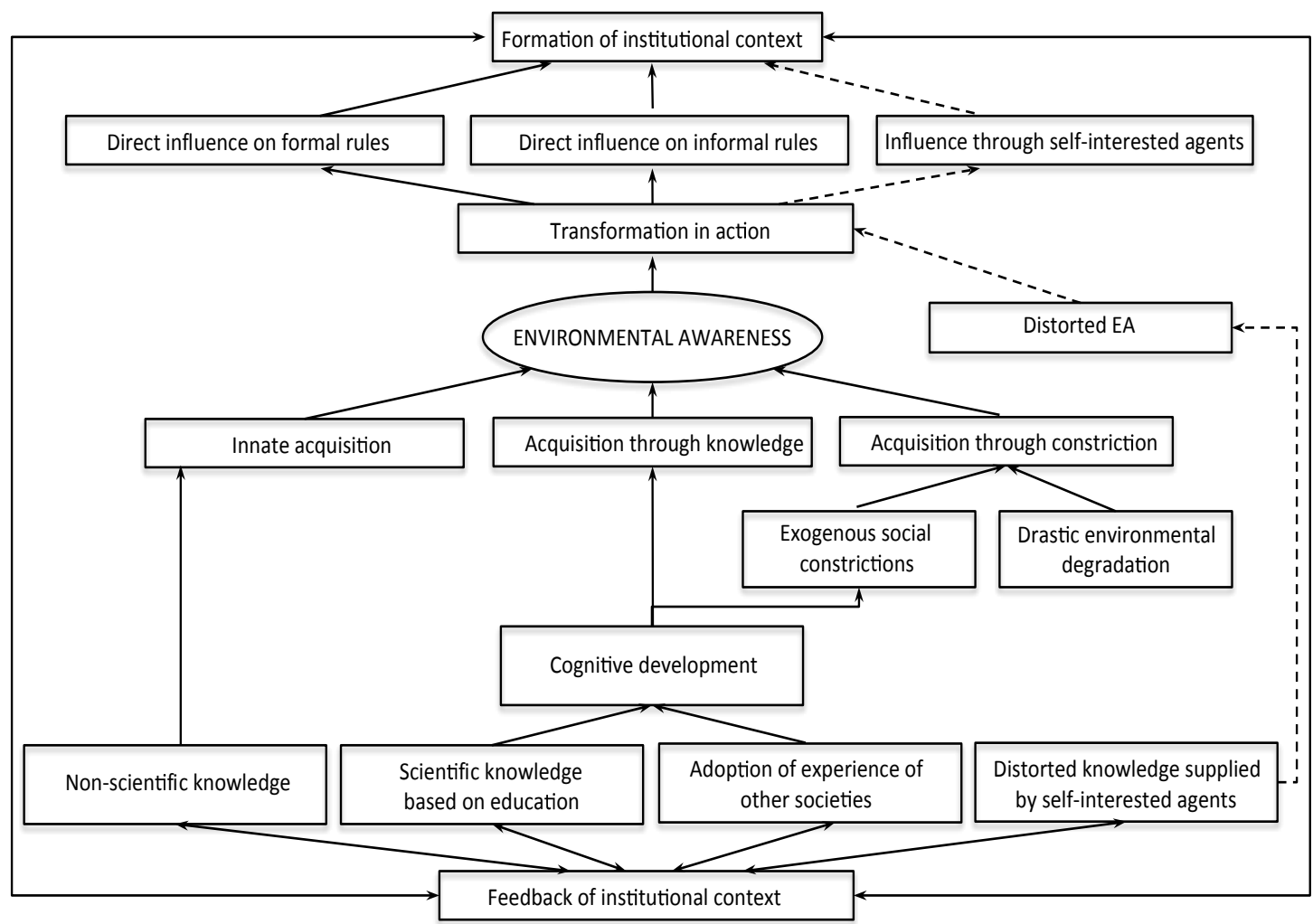

Figure 2. Interrelationship between environmental awareness and institutional context

\section{Conclusions}

In this paper we have made an attempt to analyse the main factors responsible for the acquisition of environmental awareness by societies. Understanding the driving forces of environmental awareness can be a useful tool to enact a global movement versus environmental progress and enhance environmental sustainability also in the societies that are reluctant to adhere to environmental standards and regulations.

Regarding the issue of the acquisition of environmental awareness, a small amount of literature has emerged and the links between institutions and environmental concern have been rarely studied as of today. Therefore, the novelty of this study is in investigating environmental awareness from the perspective of the institutional context. This approach bears a general character and permits us to explore a wide range of aspects, based on the formation of formal and informal rules, responsible for the acquisition of environmental awareness by considering their interactions.

The investigation analyses of possible channels for the acquisition for environmental awareness, considering the complexity of the links between economic development, institutional enforcement and environment. First of all, formal rules are argued to have an important role for the acquisition of environmental awareness through the creation of a predictable and stable world, based on sharing rules and values, the supremacy of the law, a transparent juridical system and protection of rights. In fact, rule of law enforcement is supposed to have an important positive impact on environmental concern. By analysing the data on the rule of law index and on environmental preferences for different groups of countries, we show that rule of law stringency is positively related to environmental awareness. However, as we argue, so as to be efficient, formal rules should be appropriately related to resilience, which guarantees a necessary flexibility for dynamic socio-ecological systems. These factors should be carefully accounted for by a policy-maker in formatting the legal system of contemporary societies.

For environmental awareness informal rules are no less important, based on cognitive abilities which are fundamental since they establish the recognition and respect for the rights, the definition of duties, the understanding of the goals and the interests of others, and define social interactions. We underline that the formation of cognitive abilities in relation to the environment is a difficult task that, however, can be managed by a policy maker by providing necessary resources to the programmes of environmental education.

We can, therefore, conclude that economic wealth, together with the enforcement of formal rules, and purposeful 
formation of informal rules, may create a favourable framework for the acquisition of environmental awareness. However, a double causality relationship between environmental awareness and institutions always exists. To demonstrate this phenomenon and to put all the pieces of the puzzle together, we elaborate a general scheme of the interaction between environmental awareness and institutional change. As shown, the process of the acquisition of environmental awareness implies the institutional transformation that in turn has an impact on the formation of environmental awareness itself. What policy-makers at the global level need is, therefore, to find the correct mechanisms for the enhancing of environmental awareness through the interplay of targeted formal and informal rules, based on a context favourable to strong institutions.

We hope that the present work could constitute a starting point so as to give insights for further empirical research on the determinants of environmental awareness. On the basis of our results, the future analysis should be made, on the one hand, by considering institutional indicators reflecting formal rules and emphasising factors concerning the rule of law, legitimacy, the degree of violence, or corruption control. On the other hand, informal rules should be accounted for, which can be done by considering cultural backgrounds, cognitive abilities, intelligence and accumulation of human capital. Clearly, classic factors reflecting the degree of economic development and growth are to be also taken into consideration. Finally, the delicate issue of environmental predation and distortion of information regarding environmental problems with the aim of the search for rents should be carefully addressed by further investigation.

\section{References}

Acemoglu, D., Johnson, S., \& Robinson, J. A. (2001). From the colonial origins of comparative development: An empirical investigation. American Economic Review, 9(5), 1369-1401. https://doi.org/10.1257/aer.102.6.3077

Baek, J., Cho, Y., \& Koo, W. W. (2009). The environmental consequences of globalization: A country-specific $\begin{array}{lllll}\text { time-series } & \text { analysis. } & \text { Ecological } & \text { Economics, } & 68(8-9),\end{array}$ https://doi.org/10.1016/j.ecolecon.2009.02.021

Barber, N. (2005). Educational and ecological correlates of IQ scores: A cross-national investigation. Intelligence, 33, 273-284. https://doi.org/10.1016/j.intell.2005.01.001

Beck, T., Demirguc-Kunt, A., \& Levine, R. (2003). Law, endowments and finance. Journal of Financial Economics, 70(2), 137-181. https://doi.org/10.1016/s0304-405x(03)00144-2

Bernstein, D. A., Penner, L. A., Clarke-Stewart, A., \& Roy, E. J. (2006). Psychology (6th ed.). Boston: Houghton Mifflin Company.

Bhattarai, M., \& Hammig, M. (2004). Governance, economics policy, and the Environmental Kuznets Curve for natural tropical forests. Environment and Development Economics, 9(3), 367-382. https://doi.org/10.1017/s1355770x03001293

Bonini, C. (2008, June 6). Bolle false e finti trattamenti così camuffiamo i veleni. La Reppubblica. Retrieved from http://www.repubblica.it/2008/06/sezioni/cronaca/rifiuti-11/atti-commissione-parlamentare/atti-commission e-parlamentare.html

Bugaric, B. (2008). Populism, liberal democracy, and the rule of law in Central and Eastern Europe. Communist and Post-Communist Studies, 41, 191-203. https://doi.org/10.1016/j.postcomstud.2008.03.006

Carter, D. (2007, November 6). He's been fired, but Latvian corruption chief hangs on. The New York Times. Retrieved from http://www.nytimes.com/2007/11/06/world/europe/06iht-latvia.5.8221811.html

Castiglione, C., Infante, D., \& Smirnova, J. (2014). Is there any evidence on the existence of an Environmental Taxation Kuznets Curve? The case of European countries under their rule of law enforcement. Sustainability, 6, 7242-7262. https://doi.org/10.3390/su6107242

Castiglione, C., Infante, D., \& Smirnova, J. (2018). Non-trivial Factors as Determinants of the Environmental Taxation Revenues in 27 EU Countries. Economies 2, 6(1), 7. https://doi.org/10.3390/economies6010007

Chan, E. S. W., Hon, A. H. Y., Chan, W., \& Okumus, F. (2014). What drives employees' intentions to implement green practices in hotels? The role of knowledge, awareness, concern and ecological behavior. International Journal of Hospitality Management, 40, 20-28. https://doi.org/10.1016/j.ijhm.2014.03.001

Dasgupta, S., Mody, A., Roy, S., \& Wheeler, D. (2001). Environmental regulation and development: A cross-country empirical analysis. Oxford Development Studies, 29(2), 173-187. https://doi.org/10.1080/13600810125568 
Dawson, A. (2013). The social determinants of the rule of law: A comparison of Jamaica and Barbados. World Development, 45, 314-324. https://doi.org/10.1016/j.worlddev.2012.12.016

Dee, Th. S. (2004). Are there civic returns to education? Journal of Public Economics, 88, 1697-1720. https://doi.org/10.1016/j.jpubeco.2003.11.002

Dinda, S. (2004). Environmental Kuznets Curve hypothesis: A survey. Ecological Economics, 49(4), 431-455. https://doi.org/10.1016/j.ecolecon.2004.02.011

Donnelly, S. J. (2006). Reflecting on the rule of law: its reciprocal relations with rights, legitimacy, and other concepts and institutions. The ANNALS of the American Academy of Political and Social Science, 603, 37-53. https://doi.org/10.1177/0002716205282054

Ebbesson, J. (2010). The rule of law in governance of complex socio-ecological changes. Global Environmental Change, 20, 414-422. https://doi.org/10.1016/j.gloenvcha.2009.10.009

Ekins, P., Summerton, P., Thoung, C., \& Lee, D. (2011). A major environmental tax reform for the UK: results for the economy, employment and the environment. Environmental and Resource Economics, 50(3), 447-474. https://doi.org/10.1007/s10640-011-9484-8

Folke, C. (2006). Resilience: The emergence of a perspective for social-ecological systems analyses. Global Environmental Change, 16(3), 253-267. https://doi.org/10.1016/j.gloenvcha.2006.04.002

Gassebner, M., Lamlay, M. J., \& Sturmz, J. E. (2011). Determinants of pollution: What do we really know? Oxford Economic Papers, 63(3), 568-595. https://doi.org/10.1093/oep/gpq029

Gradstein, M. (2004). Governance and growth. Journal of Development Economics, 73(2), 505-518. https://doi.org/10.1016/j.jdeveco.2003.05.002

Grossman, H. I. (2001). The creation of effective property rights. The American Economic Review, Papers and Proceedings of the Hundred Thirteenth Annual Meeting of the American Economic Association, 345-352. https://doi.org/10.1257/aer.91.2.347

Haggard, S., \& Tiede, L. (2011). The rule of law and economic growth: Where are we? World Development, 39(5), 673-685. https://doi.org/10.1016/j.worlddev.2010.10.007

Haggard, S., MacIntyre, A., \& Tiede, L. (2008). The rule of law and economic development. Annual Review of Political Science, 11, 205-234. https://doi.org/10.1146/annurev.polisci.10.081205.100244

Hassan, A., Noordin, T.A., \& Sulaiman, S. (2010). The status on the level of environmental awareness in the concept of sustainable development amongst secondary school students. Procedia - Social and Behavioral Sciences, 2, 1276-1280. https://doi.org/10.1016/j.sbspro.2010.03.187

Infante, D., \& Smirnova, J. (2016). Environmental technology choice in the presence of corruption and the rule of law enforcement. Transformations in Business \& Economics, 15(1), 80-96. http://www.transformations.knf.vu.lt/37/article/envi

Innes, R. (2013). Liability rules and the environment. Encyclopedia of energy. Natural Resource and Environmental Economics, 3, 174-184. https://doi.org/10.1016/b978-0-12-375067-9.00040-1

Iyoboyi, M., \& Na-Allah, A. (2015). Policy, institutions and non-oil exports: Evidence from Nigeria. International Journal of Economics and Finance, 7(11), 1916-9728. https://doi.org/10.5539/ijef.v7n11p10

Kaufman, J. C. (2009). Creativity, intelligence, and culture: connections and possibilities. In P. Meusburger, J. Funke, \& E. Wunder (Eds.), Milieus of Creativity. Knowledge and Space (Vol 2.). Springer, Dordrecht. https://doi.org/10.1007/978-1-4020-9877-2_8

Leitão, A. (2010). Corruption and the Environmental Kuznets Curve: Empirical evidence for sulphur. Ecological Economics, 69(11), 2191-2201. https://doi.org/10.1016/j.ecolecon.2010.06.004

Leon, A., \& Kraul, C. (2013, September 21). Peru officials look to restart controversial mining projects. Los Angeles Times. Retrieved from http://articles.latimes.com/2013/sep/21/world/la-fg-wn-peru-mining-projects-humala-20130920

Liang, C. Y., \& Wu, T. C. (2013). Is social security harmful to the environmental quality? International Journal of Economics and Finance, 5(12), 110-120. https://doi.org/10.5539/ijef.v5n12p110

Min, W. (2011). An analysis on environmental awareness and behavior in Chinese hospitality industry: A Case of Xiamen City. Energy - Procedia, 5, 1126-1137. https://doi.org/10.1016/j.egypro.2011.03.198 
North, D. C. (1989). Institutions and economic growth. An historical introduction. World Development, 9, 1319-1332. https://doi.org/10.1016/0305-750x(89)90075-2

OECD (2008). Environmental outlook to 2030. Paris: OECD. https://doi.org/10.1787/9789264040519-en

Perron, G. M., Co^te, R. P., \& Duffy, J. F. (2006). Improving environmental awareness training in business. Journal of Cleaner Production, 14, 551-562. https://doi.org/10.1016/j.jclepro.2005.07.006

Portela, I. (2012). The erosion of the rule of law in crisis times. TÉKHNE - Review of Applied Management Studies, 10, 112-119. https://doi.org/10.1016/j.tekhne.2012.11.001

Rindermann, H. (2008). Relevance of education and intelligence for the political development of nations: Democracy, rule of law and political liberty. Intelligence, 36, 306-322. https://doi.org/10.1016/j.intell.2007.09.003

Selby, D., Jones, P., \& Kagawa, F. (2009). Sustainability promotion and branding: messaging challenges and possibilities for higher education institutions. Sustainability, 1, 537-555. https://doi.org/10.3390/su1030537

Song, M. L., Zhang, L. L., Liu, W., \& Fisher, R. (2013). Bootstrap-DEA analysis of BRICS' energy efficiency based on small sample data. Applied Energy, 112, 1049-1055. https://doi.org/10.1016/j.apenergy.2013.02.064

Stafford, S. L. (2011). How green is your campus? An analysis of the factors that drive universities to embrace $\begin{array}{llll}\text { sustainability. Contemporary } & \text { Economic } & \text { Policy, } & \text { 29(3), }\end{array}$ https://doi.org/10.1111/j.1465-7287.2010.00231.x

Tbilissi Declaration. (1977). Retrieved from http://unesdoc.unesco.org/images/0003/000327/032763eo.pdf

Tranter, B. K. (1997). Environmentalism and education in Australia. Environmental Politics, 6(2), 123-143. https://doi.org/10.1080/09644019708414330

Viorica-Torii, C. (2013). Aspects of environmental awareness training in the elementary teaching system. Procedia - Social and Behavioral Sciences, 93, 1624-1629. https://doi.org/10.1016/j.sbspro.2013.10.091

Walker, B., \& Salt, D. (2006). Resilience thinking: Sustaining ecosystems and people in a changing world. Washington, D.C: Island Press.

Weede, E. (2006). Economic freedom and development: New calculations and interpretations. Cato Journal, 26, 511-524.

Weisbuch, G. (2000). Environment and institutions: A complex dynamical systems approach. Ecological Economics, 35(3), 381-391. https://doi.org/10.1016/s0921-8009(00)00219-6

World Bank. (2017). World Governance Indicators. Retrieved from http://info.worldbank.org/governance/wgi/

World Values Survey. (2017). Retrieved from http://www.worldvaluessurvey.org/wvs.jsp

Yakita, A., \& Yamauchi, H. (2011). Environmental awareness and environmental R\&D spillovers in differentiated duopoly. Research in Economics, 65, 137-143. https://doi.org/10.1016/j.rie.2010.02.003

Yan, G., Kang, J., Wang, G., Lin, H., Zhu, J., Liu, C., Sun, W., Li, Y., \& Jin, T. (2011). Change trend of public environmental awareness in Shanghai (2007 to 2011). Energy Procedia, 16, 715-721. https://doi.org/10.1016/j.egypro.2012.01.116

Yu, F. (2012). Participation of firms in voluntary environmental protection programs: an analysis of corporate social responsibility and capital market performance. Contemporary Economic Policy, 30(1), 13-28. https://doi.org/10.1111/j.1465-7287.2010.00248.x

\section{Copyrights}

Copyright for this article is retained by the author(s), with first publication rights granted to the journal.

This is an open-access article distributed under the terms and conditions of the Creative Commons Attribution license (http://creativecommons.org/licenses/by/4.0/). 